\title{
EL CASO DEL ENDECASÍLABO ESDRÚJULO
}

\author{
Arcadio Pardo
}

Resumen: Estudio cronológico de la frecuencia de endecasílabos esdrújulos en poesía española. El esdrújulo en posición interna en el endecasílabo así como en posición final o de rima. Valor del esdrújulo en la poesía moderna.

Palabras clave: Métrica, endecasílabo, endecasílabo esdrújulo.

Abstract: Frequency's chronological study of the ante-penultimate stressed hendecasyllabe verse in Spanish poetry. Ante-penultimate stressed syllable in internal and final position, or in the rhyme. Antepenultimate stressed syllable's value in modern poetry.

Key words: Metrics, hendecasyllable, ante-penultimate stressed syllable. 

"A través del esdrújulo y sus ámbitos"

(Jorge Guillén, Clamor, La venus de Itálica)

"Misterio del esdrújulo"

(Idem, Y otros poemas, Hacia la poesía, 12)

IRVAN de encabezamiento y de justificación de este trabajo los versos de Jorge Guillén citados y estos otros que siguen, del mismo poeta, que inducen a investigar el uso que se ha hecho del esdrújulo en posición interna y final en el verso endecasílabo y, si es posible, clarificar su aportación al poema:

"Cadáveres, cadáveres, cadáveres"

(Clamor, Guerra en la paz)

"Implícita sin cálculos de límites"

"¡Córdoba! "Tábida, lúrida”, ¡Córdoba!”

"Arcangélicos Hércules hispánicos"

(Y otros poemas, Reviviscencias, 43 )

(Final, La expresión, 14) ${ }^{1}$

(Final, Fuerza bruta, 5)

Estos ejemplos ponen de manifiesto no sólo que el empleo del verso endecasílabo esdrújulo ha alcanzado la tolerancia total, sino también que las voces proparoxítonas pueden ser recurso rítmico o semántico y aportar nuevas connotaciones al poema.

Como ocurrió con el endecasílabo agudo, ${ }^{2}$ el endecasílabo

${ }^{1}$ En Final, La expresión, 14, I, Guillén pone como cita estos versos de Juan de Mena:

"la cara que muestras a los del infierno

faré que demuestres al cielo superno,

tábida, lúrida y sin alabança". (Laberinto de Fortuna, 250, 8).

Los términos "tábida" y "lúrida" son latinismos con significado de "corrompida" el primero y "descolorida" el segundo".

Juan de Mena, por otra parte, ha dejado en el Laberinto algún verso compuesto por esdrújulos únicamente, aunque, naturalmente, no en endecasílabos. Por ejemplo:

trágicos, líricos, elegíanos,

cómicos, sátiros, con eroístas (Laberinto de Fortuna, 123, 5-6).

${ }^{2}$ Véase Arcadio PARDO, "El caso del endecasílabo agudo", Sevilla, Rhythmica III, 2006. 
esdrújulo también fue sometido a polémica sobre la licitud o ilicitud de su empleo, aunque la tolerancia respecto a este verso esdrújulo haya sido siempre mayor que respecto al agudo, sencillamente porque en lengua italiana existen voces proparoxítonas y había antecedentes de su empleo (sdrucciolare).

La posición de los tratadistas a este respecto se encuentra en la misma bibliografía citada a propósito del agudo, o sea, fundamentalmente en los trabajos de Emiliano Díaz Echarri, Teorías métricas del siglo de oro y de José Domínguez Caparrós, Contribución a la historia de las teorías métricas del siglo XVIII y $X I X$. Tomás Navarro Tomás indica que se ha concedido "fama de inventor de la rima esdrújula al escritor canario Cairasco de Figueroa" (1533-1610). ${ }^{3}$ Este mismo investigador señala el trabajo que Elías Zerolo dedicó al "inventor" canario. ${ }^{4} \mathrm{Y}$ también la parte que Francisco Rodríguez Marín dedica a este verso en su libro Luis Barahona de Soto. ${ }^{5}$

A Fernando de Herrera -hostil a los endecasílabos agudoslos versos esdrújulos en general no le merecen ni aprobación ni censura. Considera que el esdrújulo final de verso es consecuencia de la sustitución por el poeta de un pie troqueo por uno dáctilo (haga / hágase, por ejemplo). Y viene a concluir con estas palabras: "Son versos volubles, mas aunque el acento en la antepenúltima los acelera, el número i crecimiento de sílabas los detarda". 6

La opinión de los tratadistas es diversa y a veces peregrina. Hay quien los tolera, "pero más elegante es que sean todos [los versos] esdrúxulos" (P. Carvallo), o bien se admiten en composiciones jocosas (Munárriz) -como los agudos-; hay quien los admite "usándolos al principio o medio de los versos" (Luzán) y también quien ve en ellos cierto desacuerdo con la índole hispánica, "porque la precipitación a que arrastra el esdrújulo no se adapta bien a nuestra gravedad y mesura" (Jovellanos), ${ }^{7}$ en total

\footnotetext{
3 In Métrica española, Madrid, Guadarrama, 1978, pág. 262, nota.

${ }^{4}$ Elías ZEROLO, Legajo de varios, París, 1897, págs 1-104.

${ }^{5}$ Madrid, 1903, págs. 405-410.

${ }^{6}$ Francisco de Herrera, Anotaciones a la poesía de Garcilaso, ed. de Inoria PEPE y José María REYES, Madrid, Cátedra 516, 2001, 822 y 823.

${ }^{7}$ Estas cotas proceden de José DOMÍNGUEZ CAPARROS, Contribución a la historia de las teorias métricas del siglo XVIII y XIX.
} 
contradicción con la calidad de "misterio" y el "ámbito" que le concede al verso, como dijo Jorge Guillen en los versos arriba citados.

\section{1) Esdrújulos internos}

Una palabra esdrújula de tres sílabas aislada equivale a un pie dactílico. La sílaba breve media es la de menor intensidad y por ello mismo la más frágil. Infinitos ejemplos de reducción de nombres de ritmo dactílico a ritmo trocaico se encuentran en el vocabulario general y también en la toponimia (frigidus $>$ frío,etc). De ello resulta que en las palabras esdrújulas actuales, la sílaba final refuerza en cierto modo su intensidad y puede atraer a sí la primera sílaba breve de la palabra siguiente y formar con ella un pie trocaico: es el caso de:

de cabellos en lágrimas bañados (Francisco de Aldana, Faetonte.)

donde el pie dactílico lá-gri-mas, separa su sílaba final que viene a unirse a la sílaba siguiente, resultando:

lá- gri / mas-ba, o sea dos pies trocaicos.

Lo mismo puede ocurrir con las voces esdrújulas de más de tres sílabas. En el verso de J. Guillén:

Cadáveres, cadáveres, cadáveres

se distinguen claramente los pies trocaicos formados a partir de la última sílaba de las palabras esdrújulas:

dá-ve / res-ca / dá-ve / res-ca / dá-ve

Así pues, la palabra esdrújula en posición interna puede engendrar por combinación con la palabra siguiente dos pies trocaicos. Se puede hacer la experiencia sustituyendo en un verso la palabra esdrújula por otra que no lo es, obteniendo en cambio la misma melodía rítmica. Podemos transformar el verso de Hurtado de Mendoza: 
Abalejos con lágrimas bañados

a ba ] lejoscon / lágri / masba [ñados

(Soneto XVII)

por ejemplo, en este otro

Abalejos con sol de oro bañados

aba] lejoscon / soldeo / roba [ñados

sin que el ritmo del verso haya sufrido modificación:

Puede hacerse esta experiencia con otros versos que presentan endrújulos internos:

Confiésate, confiésale su angustia

(Unamuno, El C. de Velázquez)

tiene el ritmo siguiente:

con] fié-sa / te-con / fié-sa / le-suan [gustia

Igualmente, cuando la palabra esdrújula está en posición incial, aunque ocurre en este caso que la fragmentación de la palabra esdrújula pueda a su vez provocar la formación de otro pie dactílico distinto:

ruégate este cautivo que no tengas

(Diego H de Mondoza, Carta II)

ruéga / teestecau / tivo / que no [tengas,

donde aparece el conjunto datílico testecau.

De tal modo la palabra esdrújula en la lengua hablada puede tener en el ritmo del verso otro comportamiento. Una palabra esdrújula no es siempre un pie dactílico.

Aún admitiendo lo anteriormente dicho, es por otra parte indudable que la palabra esdrújula, por la cargazón que el recitado concede a la sílaba tónica, por su situación dentro del verso, por la puesta en relieve del concepto que transmite, por el realce que le da el acento según su posición, debe ser considerada como elemento rítmico en sí, aunque el juego métrico del verso pueda ofrecer otras soluciones.

Conviene señalar que el empleo lícito de palabras proparoxítonas en el interior del verso (Luzán) ha tenido amplia realización, pudiendo ocurrir que la estructura del verso se repita en autores 
distintos. ${ }^{8}$ Por ejemplo, el tan conocido verso de Garcilaso:

Flérida para mí dulce y sabrosa

se trasparenta en otros poetas, como en Gutierre de Cetina:

Dórida, y dice así viéndoles tales

Las palabras esdrújulas que aparecen frecuentemente en posición inicial son a menudo en la poesía italianizante y en la posterior, nombres propios poniendo de relieve por encabezar el verso con sílaba tónica, el nombre de personas o seres mitológicos:

Júpiter, ¿cuántas formas mudaría Céfiro, viste en monte, en prado, en llano Hércules le arrojó con paso horrendo Tántalo de las selvas y las fuentes
(Francisco de Medrano, son. XXIII)

(Id, Sobre el bien de la vida retirada)

(Lope de Vega, Amarilis)

Numerosísimos son los casos de utilización de la palabra esdrújula, sea nombre propio o sustantivo común, en el interior del verso, pudiendo producir un efecto sonoro relevante cuando, como en el ejemplo que sigue, aparecen dos palabras esdrújulas con fonética próxima y alternancia de fonemas: túmu / tála e intercambiando la consonante de las sílabas media y final, / túmulo / tálamo:

que un túmulo por tálamo escogiera

(Juan de Arguijo, son. XIX)

o por simple yuxtaposición:

víctimas aromáticas de nieve que líquidos aljófares sembrando

(P. Soto de Rojas, Mansión sexta)

(Id. Fragmento VII)

o también con un esdrújulo en posición inicial de cada uno de los dos segmentos del verso:

Dórida, y dice así / viéndoles tales (Citado arriba),

$\overline{8}$ La utilización de voces esdrújulas en posición inicial de verso (y también en posición inicial de hemistiquio, o de los dos hemistiquios), es frecuente en la poesía medieval. Puede ocurrir que el esdrújulo se produzca cuando aparece añadida a la palabra una sílaba átona o una e paragógica. 
con creación en ese caso de formas bimembres:

Músico llanto en / lágrimas sonoras

lúbrica muerte en / círculos torcida
(F. de Quevedo, soneto VII)

(Id, Soneto XXIII),

o sencillamente con la concurrencia de dos (o más) voces proparoxítonas en el verso:

quejándose con bárbara arrogancia el ímpetu a sus lágrimas enfrena

Aguárdalos el tálamo gozoso

De líquidos aljófares sembrando

ya cándidas, ya nácares, ya rojas

mirábanse los árboles mayores
(Lope de Vega, Amarilis)

(Juan de Arguijo, Son. XVIII)

(P. Soto de Rojas, Fragmento IV)

(Id, Fragmento VII)

(Lope de Vega, Amarilis)

(Id.).

Conviene señalar que la palabra esdrújula puede encontrarse en el verso próxima a una voz aguda (o monosílaba) reforzando su valor significante al estar en posición acentuada:

lágrimas fueran voz, lenguas mis ojos

y en vez de dulce humor, lágrimas beba

mas viéndome morir, siempre decía

o provocando formas bimembres:
(Id.: acentos en $1^{\mathrm{a}}, 6^{\mathrm{a}}$ y $\left.7^{\mathrm{a}}\right)$

(P. Soto de Rojas, Fragmento II: acentos en $6^{\mathrm{a}}$ y $7^{\mathrm{a}}$.)

(Lope de Vega, Amarilis: acentos en $2^{\mathrm{a}}$ y $6^{\mathrm{a}}$ y $\left.7 \mathrm{a}\right)$. vírgenes bellas, jóvenes lucidos

pétalos rosa de pureza angélica
(L. de Góngora, Soledades).

(Unamuno, Rimas de dentro,

"Viendo dormir a un niño")

de célica visión místico vuelo(Ibid.).

El poeta puede situar las voces esdrújulas en versos contiguos pudiendo producirse como un eco sonoro encadenado. El efecto se identifica en el ejemplo siguiente por encontrase en él, además, contigüidad de esdrújulo y agudo, la bimembración del primer verso y la posición en $6^{a}$ sílaba de la sílaba aguda de infeliz, además de la alternancia de fonemas iniciales: pro / pre:

Pronóstico infeliz, presagio duro

(Juan de Arguijo, XIX)

La proximidad de palabras esdrújulas en versos contiguos es relativamente frecuente. Alguna vez, como en el soneto "Describe un monte sin qué ni para qué", de Lope de Vega (Rimas 
humanas y divinas) hay como una concurrencia de voces de ese tipo en la misma composición:
guarnecidas de frágiles helechos
v. 2
a su margen carámbanos deshechos
v. 3
compitiendo con él cándidos pechos
v. 9
$y$ en ese monte y líquida laguna

O bien con adjetivos superlativos, como en estos versos de Espronceda:

angélica, purísima y dichosa,

oigo tu voz dulcísima y respiro

(Canto a Teresa)

Finalmente, pueden encontrarse versos endecasílabos formados por componentes esdrújulos solamente, como en el citado más arriba de Jorge Guillén y otros:

¡Córdoba, Tábida, lúrida, Córdoba!

poseyéndole en ímpetu genésico
(Final, La expresión, 14)

(Gerardo Diego, Mi Santander,

El padremadre mar);

(la sinalefa impide, en este segundo ejemplo, que la sílaba en separe los esdrújulos.)

amándote, olvidándote y negándote

(Luis Rosales, Aprendiendo a ser hombre)

o con utilización de un mismo esdrújulo en posiciones inicial y final de verso:

deshaciéndose en olas, deshaciéndose

(Id., Mi primera resurrección fue en Santander)

Las palabras esdrújulas utilizadas son con frecuencia, como ya se ha señalado, nombres de la mitología que designan dioses o encubren personas del entorno del poeta. Aparecen a menudo Júpiter, Tántalo, Tíndaro, Céfiro, y Flérida, Dórida, Lísida, Filódece, Dinámede, Eurídice:

Filódece, Eurídice, Climene

(Garcilaso, Egloga III), 
o palabras en uso en la poesía renacentista y barroca: álamo, áspero, bárbaro, espíritu, éxtasi, lágrima, lástima, líquido, pálido, púrpura, rígido, tálamo, término, túmulo, vírgenes, etc. Supertalivos como dulcísimo, excelentísimo, son usados con no poca frecuencia. Más adelante se verán casos abundantes en Jorge Guillén.

Las voces esdrújulas se utilizan de modo que el acento tónico de la palabra coincida con un acento métrico definitorio:

Acento en $1^{\mathrm{a}}$ :

Lágrimas fueran voz, lenguas mis ojos (L. de Vega, Amarilis)

Acento en $2^{\text {a. }}$

y en lágrimas el pecho el amor vuelve (F. de Herrera, Estanzas segundas.)

Acento en $3^{\mathrm{a}}$ :

y las lágrimas saben que he venido

(F.de Quevedo, Canta sola a Lisi.)

Acento en $4^{\text {a. }}$

y sumo pájaro de las lingüísticas

Acento en $6^{\mathrm{a}}$ :

de cabellos en lágrimas bañados

(Julio Herrera y Reissig, Reina del harpa y de amor)

(F. de Aldana, Faetonte.)

Acento en $7^{\mathrm{a}}$ :

y en vez de dulce humor, lágrimas beba

(P. Soto de Rojas, Fragmento II.)

Acento en $10^{\mathrm{a}}$ :

cuyo verdor abonan nuestras lágrimas

(Unamuno, El C. de Velázquez.)

No se han encontrado en los endecasílabos ejemplos con acento en $5^{\text {a }}$ (a causa del acento central en $6^{\mathrm{a}}$ ), ni en $8^{\mathrm{a}}$ (que necesitaría un monosílabo en $11^{\mathrm{a}}$ ); la introducción en esas sílabas de un pie dactílico dificultaría la construcción armónica del verso. El verso con esdrújulo en $4^{\mathrm{a}}$ es también excepcional. El ejemplo citado presenta un ritmo no habitual.

El modernismo multiplica la utilización del esdrújulo, tanto en situaciones internas como en posición inicial: 
Quimérico a mi vera concretaba

Henchíase tu alma de la audacia

Mirándote en lectura sugerente

o en concurrencia con otro esdrújulo interno:

Hierática, perdiéndote a los lejos
(Julio Herrera y Reissig, La sombra dolorosa).

(Id., Redención)

(Id., Sepelio)

Los esdrújulos internos del poema "Responso a Verlaine", incluido en Prosas profanas, de Rubén Darío, no se encuentran en versos endecasílabos. Se citan aquí por la magnificencia que aportan y que corresponde con el tono enfático del poema:

Padre y maestro mágico, liróforo celeste,

que al instrumento olímpico y a la siringa agreste

diste tu acento encantador.

Merecen se citen dos versos de Leopoldo Lugones, de su libro Las montañas de oro, en los que un mismo superlativo esdrújulo se repite en la misma posición; son dos versos contiguos:

un país con altísimos abetos,

con abetos altísimos en donde (Metempsicosis),

Tres versos, también consecutivos, tienen palabra esdrújula en igual posición en el segundo cuarteto del soneto "Alcoba solitaria”, del libro Crepúsculos del jardín:

Sentia el violin entre prolijas

Sugestiones, cual lánguida burbuja

Flotar su extraña anímula de bruja

Ahorcada en las unánimes clavijas.

Suele darse con cierta frecuencia la contigüidad en un mismo verso de voz esdrújula y de voz aguda, como si se estableciese entre ambas voces una especie de ley de compensación. He aquí algunos ejemplos:

los términos saber todos no quieren mas viéndome morir siempre decía sellando la piedad lúgubre y rica si la bóveda azul del sol, oído se ciega en explosión paradisíaca
(Góngora, Soledades)

(Lope de Vega, Amarilis)

(L. Lugones, Cisnes negros)

(Unamuno, El C. de Velázquez)

(J. Guillén, Cántico) 
$\mathrm{O}$ bien en lo que se pudiera denominar contigüidad a distancia en el interior del verso:
$Y$ vinieron también las siestas mórbidas
(L. Lugones, A los ganados y las mieses)
Brillarán, venerables $y$ católicas
(A. Machado, El mañana efímero)

\section{2) Esdrújulos en posición final}

El litigio en torno a la licitud de agudos o esdrújulos se refiere, especialmente, naturalmente, a los casos en que esas voces se encuentran en posición final de verso (o de rima). Las páginas que siguen tratan de investigar cual ha sido desde la adopción del endecasílabo italiano, la frecuencia de su utilización.

Son escasísimos, si los hay, los esdrújulos en posición final de verso en los siglos XVI y XVII. Si Francisco López de Úbeda dio un soneto en agudos en La pícara Justina (1605), también nos ofrece dos octavas en esdrújulos en la misma obra. ${ }^{9}$

Juan de Arguijo (1567-1622) abrumado por sus asuntos en quiebra, se refugió en la Casa profesa de la Compañía en Sevilla donde escribió a modo de epístola una ristra de 213 endecasílabos blancos con esdrújulos en posición final:

a mí mismo me engaño prometiéndome, como si fuera cierto, un bien fantástico y sobre tanto mal, sucesos prósperos, una salud segura y tiempos fértiles

(A un religioso de Granada).

El mismo Arguijo compuso otro poema en 57 endecasílabos esdrújulos blancos que tituló "Esdrújulos del Hermano Carlos de Mendoza". Estas dos composiciones son las primeras que utilizan ese tipo de verso para asuntos serios y constituyen un verdadero repertorio de voces esdrújulas de la época, y una proeza de virtuosismo.

La liberación del esdrújulo en posición final de verso y/o de hemistiquio se va a producir con la renovación modernista. Apa-

\footnotetext{
${ }^{9}$ Las dos octavas se encuentran en el libro primero intitulado La pícara montañesa, capítulo primero, número primero: «Al comenzar Justina entró Pelícaro», etc. Pueden verse en la edición reciente: LÓPEZ DE ÚBEDA Francisco, La picara Justina, ed. de Juan Ignacio FERRERAS, Antonio REY HAZAS y Rosendo GARCIA RAMOS, León, Lobo Sapiens, 2005.
} 
recen con el nuevo movimiento poético una infinidad de combinaciones de voces esdrújulas, sobre todo en versos compuestos, en concurrencia con otras voces esdrújulas y también con voces agudas. Rubén Darío, por ejemplo, en versos que son una combinación de heptasílabo y decasílabo $(7+10)$ utiliza en situación de rima y en forma alternada, voces agudas y esdrújulas, y al mismo tiempo sitúa otros esdrújulos en final de hemistiquio, e incluso yuxtapone dos esdrújulos (Atmósfera cálida):

¡Oh, reina rubia -díjele,- mi alma quiere dejar su crisálida

$y$ volar hacia ti, y tus labios de fuego besar,

y flotar en el nimbo que derrama en tu frente luz pálida,

$y$ en siderales éxtasis no dejarte un momento de amar.

El aire de la noche refrescaba la atmósfera cálida.

Venus desde el abismo me miraba con triste mirar .

(Azul, Venus).

El poeta Julio Herrera y Reissig también utiliza rimas esdrújulas en versos compuestos, como en su soneto "Las arañas del augurio". ${ }^{10}$

En El canto errante, de Rubén Darío, se encuentra este serventesio en verso dodecasílabo $(7+5)$ :

¡Desgraciado Almirante! Tu pobre América

tu india virgen y hermosa de sangre cálida,

la perla de tus sueños, es una histérica

de convulsivos nervios y frente pálida.

${ }^{10}$ Incluido en Las Pascuas del Tiempo dice así:

Yo sé que sus pupilas sugieren los misterios

De un bosque alucinado por una luz exótica;

Yo sé que entre sus sedas luce una fuga erótica

que sueña en ideales y lácteos hemisferios.

Para mis penas fueran divina magia hinóptica

Sus labios incensarios de místicos sahumerios;

$Y$ yo deseara siempre tener por cautiverios

Sus brazos, sus cabellos y su nostalgia gótica.

Oh, si pudiera hallarla! Soñaba en este día

Que ilusionó el palacio de mi melancolía;

Sus finas manos, ebrias de delirar armónicas

Dulzuras de los parques, vagaban en el piano

Sonambuleando y eran las blancas filarmónicas

Arañas augurales de un mundo sobrehumano. 
Endecasílabos con esdrújulos en rimas se encuentran en el soneto "Reina del harpa y del amor", del mismo Herrera y Reissig, con un caso de yuxtaposición ("pájaros románticos") y presencia en rima de dos voces agudas en tos versos 11 y 14 :

Evocadora de Jerusalenes

$Y$ de las graves Afroditas místicas,

De Salomón el creador de harenes

Y sumo pájaro de las lingüísticas...

Duermen tus manos de prerrafaelísticas

Insinuaciones todos mis vaivenes:

Manos que son custodias eucarísticas

Para las regias hostias de tus sienes.

Vamos a Dios! Entre floridos cánticos,

Piquen tus dedos pájaros románticos,

El harpa antigua del vergel de Sión...

$Y$ alzando a ti mi beso en un hinóptico

Rapto de azul, como en un cáliz gótico

Beberé el vino de tu corazón.

El vocabulario esdrújulo modernista se distingue por la adopción de términos de uso común reducido o especializado, y también correspondiente a la boga que adquieren por esos años los estudios de psicoanálisis: clorótico, eucarístico, filarmónico, funámbulo, hipnótico, lingüístico, místico, narcótico, neurasténico, sonámbulo, etc.

Leopoldo Lugones ofrece numerosísimos casos de empleo de esdrújulos, tanto en posiciones internas como en posición final, en verso suelto, o en versos rimados. Casos de concurrencia de esdrújulos tampoco escasean:

cual minúscula lámpara en el túmulo

y tus ojos abríanse sonámbulos

En el párpado lóbrego de la uva
(Antífonas)

(A Histeria)

(A los ganados y a las mieses)

"La Rima de los ayes" es un romance endecasílabo con asonancia en ÁA en el que se encuentran varios versos con esdrújulo en posición de rima. He aquí algunos de ellos: 
tenían los fulgores de mi lámpara que se siente caer como una lápida mi concubina desolante y pálida tras el perfil de la frontera atávica. ÓO:

En "La vendimia de la sangre", los versos tiene asonancia en y en dos partido su blasón histórico donde trazan fatídicos horóscopos

En rima consonante aparecen esdrújulos en formas estróficas diversas. "Antífonas" está escrito en tercetos en los que los versos 1 y 3 de cada terceto son idénticos resultando repetida la palabra en rima y quedando los versos interiores sueltos: AXA, $\mathrm{BXB}, \mathrm{CXC}$, etc.

Como el pudor de la vejez es pálido,

Conservemos su frio, porque el frio,

Como el pudor de la vejez es pálido,

En rima consonante se encuentran en la obra de Lugones algunos esdrújulos. He aquí un serventesio:

Gotea oro una fuente sin murmullo...

$Y$ al rayo diagonal del sol escuálido,

Sobredora el jilguero su capullo

Allá en el sauce cada vez más pálido.

(Horas doradas, El oro del otoño),

Es sabido que L. Lugones escribió poemas de medida libre, haciendo a veces rimar los versos sin atenerse a un orden. Los versos que siguen se encuentran en uno de esos poemas no rimados, y se incluyen aquí, a modo de ejemplo, como endecasílabos de final esdrújulo utilizados también en aquella modalidad. Son dos versos seguidos del poema "Los mundos", recogido en Poesías diversas. ${ }^{11}$

Luego inquiere la causa de recóndita

Perturbación y con pupila impávida

${ }^{11}$ Leopoldo LUGONES, Obras poéticas completas, Madrid, Aguilar, 1959. 
Nada tan elocuente como los versos que siguen para admitir la complacencia que Miguel de Unamuno debió sentir respecto a los esdrújulos que designan lugares de España y en los que él veía "el tuétano" de la lengua:

\author{
Ávila, Málaga, Cáceres, \\ Játiva, Mérida, Córdoba, \\ Ciudad Rodrigo, Sepúlveda, \\ Úbeda, Arévalo, Frómista, \\ Zumárraga, Salamanca, \\ Turégano, Zaragoza, \\ Lérida, Zamarramala [...] \\ el tuétano intraductible \\ de nuestra lengua española.
}

También son elocuentes los poemas "En la basílica del Señor Santiago de Bilbao" y "Las magnolias de la plaza nueva de Bilbao", ambos en estrofas de cuatro versos sin rima formadas por tres endecasílabos y un pentasílabo. Pues bien, en ambos poemas el verso final de cada estrofa es esdrújulo El primero de estos dos poemas se compone de treinta y seis estrofas y el segundo de once, que representan cuarenta y siete palabras esdrújulas en posición final de pentasílabo. ${ }^{12}$

Estos tres poemas parecen anunciar un empleo abundante de esdrújulos en la poesía de este poeta. Como ya se hizo en el estudio dedicado al endecasílabo agudo, también ahora conviene observar separadamente el gran poema que es El Cristo de Velázquez del resto de su obra.

Sea en posición interna o en posición final, Unamuno utiliza el esdrújulo desde su primer libro Poesías. De "La torre de Monterrey" son los dos versos que siguen, observándose en el segundo una inversión de términos con voluntad quizá de insistencia:

\footnotetext{
De "En la basílica del Señor Santiago de Bilbao":

Entré llevando lacerado el pecho,

convertido en un lago de tormenta,

entré como quien anda y no camina,

como un sonámbulo

De "Las magnolias de la plaza nueva de Bilbao":

iMi Plaza Nueva, fría y uniforme,

cuadrado patio del que el arte escapa;

mi Plaza Nueva, puritana y hosca,

tan geométrica!
}

${ }^{12}$ Sirvan de ejemplo las primeras estrofas de cada uno de los dos poemas : 
a la unción de la luna melancólica

De la luna la unción por arte mágica

En el poema dedicado "A la catedral de Barcelona" aparece algún verso terminado en esdrújulo con palabras en consonancia con el tema:

desnudas las columnas, en mis bóvedas

habita en mi el espíritu católico

Las palabras esdrújulas del poema "Por dentro" tienen ya una resonancia del vocabulario que se empleará más tarde el El Cristo de Velázquez:

con un vivir oscuro y abismático

es el dolor eternizado el único

Y también en la "Elegía a la muerte de un perro" donde la palabra "espíritu" aparece en posición interna y también en posición final:

¿Dónde se fue tu espíritu sumiso?

¡El otro mundo es el del puro espíritu!

que reaparece en "Recuerdos" con connotaciones que le acercan a los ejemplos anteriores:

En el oscuro abismo de tu espíritu

que vuelve a encontrarse en "Sin sentido":

si os limpié de conceptos el espíritu.

En "Caña salvaje" del libro Rimas de dentro, el poeta recupera el vocablo realzándolo ahora con otro esdrújulo situado en posición inicial:

Ríndete al soplo del Señor, tu Espíritu

El Romancero del destierro, ofrece un verso que bien pudiera figurar en El Cristo:

en las manos de Dios puso el espíritu (TETE $\Lambda$ ELTAI). 
Todas los versos citados a este propósito permiten afirmar que esa palabra tiene uso preferencial en la obra de este poeta.

En las misma posiciones inicial y final se encuentran en otros versos:

pétalos rosa de pureza angélica

callábamos los dos y nos mirábamos
(Rimas de dentro, "Viendo dormir a un niño")

(Teresa, "Mi corazón latía contra el hierro")

Se ha señalado más arriba un caso de alternancia fonética en un verso de Juan de Arguijo:

que un túmulo por tálamo tuviera (túmulo / tálamo);

pues bien, en el Cancionero de Unamuno hay un caso que merece ser citado. Se encuentra en el poema "Biriatu" en el que hay dos esdrújulos asonantados que presentan también la alternancia "pálidas / lápidas". He aquí los versos donde se encuentran:

Cantaba la iglesilla en la verdura;

voz en agraz de muchachitas pálidas

vertíanse en el claro cementerio

yendo a posarse encima de las lápidas.

El conjunto de palabras esdrújulas en posición final en $E l$ Cristo de Velázquez es inferior al de palabras agudas. Salvo error, las esdrújulas en esa posición son 132.

-ESPÍRITU aparece 12 veces en el poema. He aquí algunos ejemplos:

nuestros ojos, las manos el espíritu que con sus manos recogió tu espíritu

y a dormir a la sombra del Espíritu
(Primera parte, III)

(Segunda parte, I)

(Tercera parte, XIX)

\section{-LÁGRIMA/S ” aparece 7 veces:}

Sobre tu cuerpo, ya arrecido, lágrimas cuyo verdor abonan nuestras lágrimas sólo una sola nube con las lágrimas
(Primera parte, XVI)

(Id, XXIII)

(Segunda parte, VII) 
La mayor parte de las palabras esdrújulasas en posición final tienen connotaciones bíblicas o bien recogen símbolos cristianos o atributos de la persona de Cristo, o personajes de los evangelios: adúltera, águila, ánfora, ángeles, apólogo, apóstoles, basílica, bóveda, brújula, cándido, cántico, discípulos, féretros, Lázaro, místico pábulo, parábola, púrpura, tránsito, túnica, único, vírgenes.

Algunos de los esdrújulos utilizados lo son por haberse formado con una forma verbal, personal o no personal, a la que se ha añadido uno o dos pronombres enclíticos. Son relativamente numerosos los casos, entre ellos los siguientes:

milagro es este del pincel mostrándonos del pan que nos enseñas a ganárnoslo de tu sangre a las raíces aterrábase el ayer y el mañana en uno cuájanse almas del mundo trémulas, pidiéndote sin asiento, de paso; mas recógenos
(Primera parte, III)

(Id., XXXVII)

(Segunda parte, VIII)

(Tercera parte, XII)

(Cuarta parte, VII)

(Oración final)

Así pues la utilización del esdrújulo en la obra de Unamuno es amplia, variada, con aportación de significados y de connotaciones diversos; empleo libre y abundantemente aceptado a lo largo de su creación, apareciendo el esdrújulo en posiciones internas o en rima o en versos blancos que demuestran que el verso esdrújulo, y en particular el endecasílabo esdrújulo, tiene su lugar en el poema en igualdad con las palabras de distinta naturaleza fonética.

Juan Ramón Jiménez utiliza esdrújulos desde los primeros poemas de su obra:

\section{Los gallos}

erguidos, metálicos,

asustan los pálidos

luceros.

O bien en estos otros versos de Baladas de primavera:

Vámonos, vámonos al campo por romero, vámonos, vámonos, por romero y por amor.

(Baladas de primavera, Balada de la mañana de la cruz). 
Una alta proporción de palabras esdrújulas aparecen en poemas en versos mayores compuestos por ser ese tipo de verso el más usado por el poeta en su obra inicial, tanto en posición interior como en posición final de versos o de hemistiquios:

el acaso, una música imposible y romántica (Poemas agrestes, Retorno)

temblara cual un mágico crepúsculo de música (Laberinto, XVIII)

He aquí algunos endecasílabos con final esdrújulo espigados en la obra de esa primera época:

se estasiaban las flores y los pájaros

bando de golondrinas que el sol último
(Rimas de sombra, Recuerdos)

(Olvidanzas, Niño)

En Poemas májicos y dolientes aparecen otros casos:

de ojos celestes y cabellos áureos

para la melodía de tus cánticos

bajo la magia de tus dedos pálidos
(Otoño)

(Ibid.)

(Ibid.)

Estos tres versos riman con asonante -ÁO. El poema se compone de tres estrofas de cuatro versos donde, como se ve, la proporción de esdrújulos es elevada.

"La luna velada", del mismo libro, es una silva compuesta por versos de diversas medidas y asonantados en -ÁA. Una de sus "estrofas" termina con este verso:

¿Es que me muestras tus delicias cándidas?

En este mismo libro se encuentran otros endecasílabos esdrújulos:

y vas a dar una esperanza lírica

Después la tarde cae... Y el crepúsculo

me hastían de colores y de bálsamos

y se cierran de nuevo; y es tan lánguido
(Jardín en el espejo)

(Ibid., verso suelto)

(Poemas májicos y dolientes,

Languidez)

( $P$ m. y d., Languidez)

Uno de los versos esdrújulos de este mismo libro presenta, además de su rima propia asonante en -ÁA, la misma rima en palabras que componen el verso: 
que hace pensar en otro verso, aunque alejandrino, con una fuerte resonancia de rimas internas:

\section{Dulces luces azules de túneles y puertos $\quad$ (Historias, Tren y buque)}

Tiene rima asonante en -ÁO el poema (silva) al que pertenecen estos otros dos versos que siguen:

de aquella cara iluminada y pálida?

de tu niñez, en el oriente májico

en el turqués de la mañana, pálido
(Citado más arriba)

(Monumento de amor, .Oberon a Titania).

Cuando los versos citados están en posición de rima, ésta se produce en asonancia.

En los últimos libros de Juan Ramón Jiménez, el recurso al endecasílabo agudo denotaba una intensa expresividad, cierta identificación del poeta con el verso de final tónico. No ocurre lo mismo en lo que se refiere al empleo del endecasílabo esdrújulo que aparece con una frecuencia bastante menor. En cambio se observa cierta complicidad entre palabras agudas y esdrújulas en posición final o en posición interna, algo que no es juego de palabras sino ampliación en la posibilidad de la expresión poética. Aunque sólo uno de los versos citados a continuación es esdrújulo, conviene señalar los cinco que forman este fragmento en que palabras agudas y esdrújulas facilitan la expresión de la comunión el poeta con los sentidos, con el universo. Nótese la presencia de palabras agudas bajo el acento en $4^{\mathrm{a}}$ :

Chorreo luz: doro el lugar oscuro, trasmito olor: la sombra huele a dios, emano son: lo amplio es honda música, filtro sabor; la mole bebe mi alma, deleito el tacto de la soledad.

(La estación total, El otoñado).

La presencia conjunta de agudos y esdrújulos repite a veces estructuras utilizadas en otras ocasiones, pero que ahora parecen ofrecer una más evidente densidad: 
exaltando su última verdad que fija con su nítida quietud
(Id., Paraíso)

(Id, Ciudad el cielo)

En los dos versos que siguen, la concentración de palabras agudas enmarcan el esdrújulo que parece desempeñar un papel de moderador, ensanchando el espacio que las palabras agudas anteriores reducen por la contundencia de sus acentos, como olas sucesivas que se derraman en ese "ámbito mayor":

El color es más él, más sólo él,

el olor sólo tiene un ámbito mayor

(Id., La plenitud)

Otro tanto puede decirse e este otro conjunto:

y la imajen

de mi devenir fiel a la belleza

se va igualando más hacia mi fin,

fundiendo el dinamismo con el éstasis.

(Animal de fondo, Río-mardesierto)

La utilización de esdrújulos en la obra de Juan Ramón Jiménez ha alcanzado no sólo plena libertad, como se ha visto en poetas anteriores, sino que además el poeta "extrae" de esas palabras esdrújulas en cualquier posición, posibilidades expresivas que se hacen perfección, melodía universal:

perfección inmanente de una música

(La estacón total, Rosa secreta).

Se observa que algunas de las palabras esdrújulas utilizadas por el poeta son recurrentes, tanto en posición interna como en posición final, y tanto en versos endecasílabos como en versos compuestos. Se deduce de ello cual es su vocabulario preferencial, el que mejor corresponde y expresa su vivencia del mundo. Se han escogido solamente endecasílabos:

-MELANCÓLICO/A/S:

con el último beso melancólico

El viento lleva sones melancólicos

que hiere los cristales melancólica

el inefable anhelo melancólico

y la luna amarilla y melancólica

se pierde en el oriente melancólico

(Rimas, Sombras)

(Ibid.)

(Laberinto, $\mathrm{n}$

(Rimas, Cuento)

(Id., La víspera)

(P. mág. y dol., Estampa de estío) 
sin mieles ya de goce, melancólicas

-Dejado goce solo y melancólico

-LÁGRIMA/S:

llega un aire perfumado, caen mis lágrimas

Nutridos del rocío de las lágrimas

y cuando resbaló la última lágrima

como a su cielo gris, deshace en lágrimas

sombríos y mojados como lágrimas...!

Me desperté de un grito aún con lágrimas

-MÁJICO/A/S:

a tu propio mar solo, ardiente y májico?

de tu niñez en el oriente májico

derramamiento de cristales májicos

como una larga galería májica

fondo tras fondo de los fondos májicos

perfecta, fiel, con la promesa májica

-PÁLIDO/A/S:

en el turqués de la mañana; pálido

bajo la magia de tus dedos pálidos de aquella cara iluminada y pálida? y la tierra de un blanco y negro pálido más realidad que mis enseueños pálidos ese negror mayor sobre lo pálido

-MÚSICA/S:

dulce es la sombra, lírica, con música al fin, en aguas vagas, entre músicas de almas de azucenas que una música La mujer, con la música, es la música perfección inmanente de una música

-LÍRICO/A/S:

y vas a dar a una esperanza lírica pensamientos de oro, rosas líricas idealidades de oro, glorias líricas inestinguibles del estio, líricas entre el ramaje lujurioso y lírico

-ROMÁNTICO/A/S:

rosa alumbrada de un rosal romántico! una vieja aguafuerte de romántico que para el triste corazón romántico
(Laberinto, Amistad de septiembre)

(Piedra y cielo, 39)

(Rimas, Nocturno)

(Id., Los niños abandonados)

(Id., Cuento)

(Monumento de amor,

Oberon a Marzo)

(Laberinto, Sentimientos

musicales, IX)

(Eternidades, 130)

(Idilios)

(Monumento de amor, Oiberón a Titania)

(Laberinto, Sentimientos musicales, VIII)

(Piedra y cielo, Rosas 1)

(Belleza, Ello)

(La estación total.,En flor)

(Monumento de amor,

OIberón a Titania)

(P. m. yd., Otoño)

(P. $m$. y d., Madrigal de ausencia)

(P. $m . y d$., Estampa de invierno)

(Laberinto, Sol de otoño)

(La estación total,Monstruo allto)

(P. m. y d., Campo de agosto)

(Laberinto, Sol de otoño)

(Diario, Partida)

(Poesía en verso, 105)

(La estación total, Rosa secreta)

(P. $m . y d$., Jardín en el espejo)

(P. m. yd., Tarde clara)

(P. m. yd., Jardín confuso)

(P. m. $y d$., Las hojas secas)

(P. $m . y d$., Paisaje a lo Boecklin)

(P. m. yd., Luna de otoño)

(P. $m . y d$., Estampa de invierno)

(Laberinto, Sol de otoño) 
nosotros somos esos dos románticos

-ÁUREO/A/S:

de ojos celestes y cabellos áureos

un hervor musical de timbres áureos

Hay una claridad de mundos áureos

Vienen esencias e otras tardes áureas

-PÁJARO/S:

suave de arroyuelos y de pájaros

cuando nacieron verdes y los pájaros

el trueno con el canto de los pájaros

-TRÁJICO/A/S:

con la muerte has crecido en una trájica

hueco propicio a las memorias trájicas
(Diario, Amor)

(P. m. $y d$., Otoño)

(P.m. y d., Tarde clara)

(P.m. y d.,stampa de estío)

(Laberinto, Amistad de septiembre)

(P. m. yd., Campo de gosto)

(P. m. yd., Las hojas secas)

(Belleza, Marzo)

(Historias, 10)

(Diario de un poeta, Remordimiento)

¿Nadie? ¡Nadie! -... ¡Con qué trabajo trájico (Diario, Eternidades, 57)

-ÉSTASIS:

abierto mudamente para el éstasis

del día que te va pasando en éstasis

fundiendo el dinamismo con el éstasis

(Estio, Jardín )

(Animal de fondo, $\mathrm{Al}$ centro

rayeante)

(Animal de fondo, Río-mar-desierto)

-ESPÍRITU:

rugiendo se derrama en el espíritu

¡cuánto más grato al cuerpo y al espíritu

(Rimas, El lago del dolor)

(Piedra y cielo, 35)

-ÁRBOLES:

a la sombra morada de sus árboles

el traje blanco iba, entre los árboles

-FANTÁSTICO/A/S:

de roces vaporoso y fantásticos

¡Por ti, livido sol, por tus fantásticas

-ESPLÉNDIDO/A/S:

primaverales, cálidas, espléndidas

más limpio cada vez entre lo espléndido

-CREPÚSCULO/S:

luz morada del plácido crepúsculo

Después la tarde cae ... Y el crepúsculo

-ÚLTIMO/S:

Don Quijote se va con el sol último

Por fuera erraba el viento oscuro y último
(P. m. yd., Paisaje a lo Boecklin)

(Laberinto, Nostaljia de agosto)

(P. $m . y d$., Luna de otoño)

(Laberinto, Sol de otoño)

(P. $m . y d$., Ciudades de ilusión)

(Estio, Jardín 1)

(Rimas, Cuento)

(P. $m . y d$., Jardín en el espejo)

(Diario, Argamasilla del mar)

(Piedra y cielo, Luz) 
En cambio otros esdrújulos que aparecen en otras posiciones y pueden considerarse característicos del vocabulario juanramoniano, aparecen en posición final de endecasílabos muy escasas veces, como ocurre con los adjetivos "lánguido" y "nostáljico",

y se cierran de nuevo; y es tan lánguido ensueños encendidos y nostáljicos
(P. máj. y dol., Languidez) (Id., Tarde clara)

Nótese, aunque puede sea un caso único en su obra, y en verso no endecasílabo, la creación de un neologismo en esdrújulo superlativo a partir del prefijo "sub"-:

y abajo, muy debajo de mí, en tierra subdísima (Animal e fondo, Con la cruz el sur).

Se cierra esta incursión en el empleo del endecasílabo esdrújulo en este poeta con unos versos de La estación total en los que parece se expresa la identificación total con el entorno del hombre, recogida en las tres palabras esdrújulas que componen el segundo verso:

no sé si eres el único

o la réplica májica del único

No hay en la obra de Antonio Machado abundancia de endecasílabos esdrújulos, pero los que se encuentran en ella vienen a ser como la esencia de su poesía. El poeta nos ha dejado esta silueta suya:

así voy yo, borracho melancólico

(Galerías, Y no es verdad dolor)

Cuando el endecasílabo esdrújulo aparece es generalmente para expresar una situación de tensión trájicamente aceptada:

y el hombre aúlla al horizonte pálido

(Id., Desnuda está la sierra)

o surgen relacionados con la muerte, como en los versos en que el poeta indaga el cante hondo:

el paso largo, torva y esquelética [...)

$y$ en la guitarra resonante $y$ trémula

(Soledades, Cante hondo) 
o en el entierro del amigo:

En otros casos el poeta se sirve del esdrújulo para crear como una visión impresionista, efímera, de la realidad del paisaje:

de la mañana. Por los montes cárdenos camina otra quimera arrebatados tras la corza rápida desde los picos donde habita el águila

Estos versos forman parte de poemas en los que se utiliza rima asonnante. Curiosamente, los versos incluidos en estrofa o poema de rima consonante tienen cierto matíz irónico que las palabras iniciales agudas, el paralelismo de los versos y la recurrencia acentual ponen de relieve:

florecerán las barbas apostólicas

brillarán, venerables y católicas

(CC, El mañana efímero)

La frecuencia de endecasílabos esdrújulos es mayor en la obra de Jorge Guillén: 562, salvo error, con una diferencia mínima respecto al número de endecasílabos agudos que era de 579 casos. Proporciones, como se ve, equilibradas. El número de endecasílabos esdrújulos es inferior al de endecasílabos agudos en Cántico, en Clamor y en Homenaje. En cambio es superior en $Y$ otros poemas y en Final:

$\begin{array}{lrl}\text { Endecasílabos Agudos en "Cántico": } & 118 & \text { Esdrújulos: } 45 \\ \text { Endecasílabos Agudos en "Clamor": } & 116 & \text { Esdrújulos: } 100 \\ \text { Endecasílabos agudos en "Homenaje" } & 128 & \text { Esdrújulos: } 126 \\ \text { Endecasílabos agudos en "Yotros poemas" } & 120 & \text { Esdrújulos: } 151 \\ \text { Endecasílabos agudos en "Final" } & 97 & \text { Esdrújulos: } 140\end{array}$

Se comprueba una progresión del empleo del verso esdrújulo en los libros últimos.

Jorge Guillén, en un hermoso poema dedicado a Itálica, habla de "el esdrújulo y sus ámbitos", intuyendo la amplitud sonora y de sentido que la palabra esdrújula incluye; el poeta encuentra 
una fórmula para expresar esa amplitud: "suene y resuene" el nombre esdrújulo, dando al motivo del poema como un eco prolongado para siempre:

Itálica:

Suene y resuene el nombre,

Vibre en él una Itálica de gente, que a través del esdrújulo y sus ámbitos

Resurja entre nosotros

Para acoger a la verdad de Venus,

Itálica.

(Clamor, La Venus de Itálica)

Y en otro lugar revela el "misterio del esdrújulo" ( $Y$ otros poemas, p. 203) sin precisar el contenido que da a este atributo de "misterio". Pero sí debemos aceptar que el poeta se sitúa con el uso del esdrújulo, en un territorio suyo mucho más cargado de significado.

No escasean en la obra de J. Guillén los casos de esdrújulos internos, ni tampoco versos que presentan esdrújulos en posiciones interna y final, ni tampoco aquellos en que aparecen conjuntamente palabras agudas y esdrújulas, o versos compuestos únicamente por palabras proparoxítonas. Se repiten aquí los versos citados como encabezamiento de este trabajo, compuestos por palabras esdrújulas:

De cánticos y máscaras decrépitas

(Clamor, Luzbel desconcertado II)

Cadáveres, cadáveres, cadáveres

(Clamor, Guerra en paz II)

Crustáceos, galápagos mecánicos

(Y otros poemas, Hombre y luna 1 )

Implícita, sin cálculos de límites

(Id., Reviviscencias 43)

¡Córdoba, Tábida, lúrida, Córdoba

(Final, La expresión, 14)

Arcangélicos Hércules hispánicos

(Id., Fuerza bruta)

En otros versos de final esdrújulo el poeta sitúa en posición acentual otra palabra esdrújula que, puesta bajo acento, cobra un relieve evidente:

Ámbito dibujado, geométrico

Esfumándose van en el crepúsculo

Sumisa a ignotos númenes $y$ números
(Cántico, Retiro de jardín)

(Homenaje, Extinción)

(Clamor, Dimisión de Sancho).

También se encuentran versos en los que un agudo se encuentra en contigüidad con el esdrújulo final: 
Yo sólo sé de mi unidad efímera

Vida secreta, corazón, crepúsculo
(Clamor, Nada más)

( $Y$ otros poemas, Elegíaco profesional)

e incluso con la palabra aguda antepuesta a dos esdrújulos contiguos, siendo el último el que halla en posición final:

Siempre en solaz, rozándose, mordiéndose (Homenaje, Romano Bilenchi I).

Las variantes son múltiples ya se trate de concurrencia de esdrújulos en el verso, ya de la cohabitación de palabras esdrújulas y agudas en él, con todas las posibilidades que ofrece la situación de las palabras bajo los acentos rítmicos, sin olvidar la creación de simetrías y bimembraciones como en el siguiente:

Razón de amor $y$ cántico de pájaros

(Y otros poemas, Guido Cavalcanti)

o en versos que presentan la misma estructura paralela en un mismo poema:

Nuestro deseo implícito de música

reajuste en imágenes las múltiples

(Final, Al lector superviviente)

o estos otros en poemas distintos:

Su hermosura con mínima retórica

(Final, Ausencia de ruido)

$Y$ regresan con vívidas imágenes

(Id. Profunda caravana)

Algunas palabras esdrújulas constituyen parte del vocabulario preferencial de Jorge Guillén. Las más frecuentes en posición final son las siguientes. Las referencias corresponden a $C=$ Cántico $; C L=$ Clamor $;=H o m e n a j e ; ~ Y O P=Y$ otros poemas; $F=$ Final:

-ESPÍRITU: 19 casos

Inferior para siempre a tanto espiritu

Nada más un espíritu en su espíritu!

Triunfo, si no de un fuego, de un espíritu

Tan ajena a un aliento que fue espiritu

Asciende hasta la cumbre de su espíritu

Que presiden y alumbran: luz-espiritu.

Como si fuera ya radioso espíritu
$\mathrm{Cl}$, Luzbel desconcertado VI"

Id., Lugar de Lázaro I"

Id., En obra"

Id., Soy mortal"

Id., Historia extraordinaria"

$H$, Al margen de César Vallejo

Id., Federico García Lorca” 
La vista imaginaria de mi espíritu

"Es sagrado el desorden de mi espíritu". Transparencia en la luz del aire-espíritu. Tan remotas y ajenas a mi espíritu Belleza de mujer y sabio espíritu Lo que en su encarnación es otro espíritu." Sin cesar a la luz de libre espíritu. Embustes. Y se engaña al propio espíritu ¿Será el tiempo invención de cada espíritu? Por entre las palabras y el espiritu Y su cuerpo es también, también espíritu. Su energía en un vértice de espíritu

\section{-LÍMITE/S: 14 casos:}

En un tiempo que no prevé sus límites. Y en su puesto, ceñido por sus límites: La criatura ha superado el límite. Todo, todo más claro hasta ese límite Principio a ver con claridad mis límites Más implacable es cada día el límite Alguna ordenación entre sus límites Alma de aquella incógnita sin límites? Consolidada en tu opresión, tus limites" Oposición del héroe a los límites.

Bien acordes los seres a sus límites Implícita sin cálculos de límites... Realizar con la angustia de los límites Sino humildad, conciencia de mis límites.
Id., Shakespeare")

$Y O P$, Arthur Rimbaud

Id., Aire nuestro I"

Id., Aire nustro IV"

Id., Guido Cavalcanti

Id., Ungaretti $\mathrm{V}$

$I d$., Reviviscencias 62

$F$, El drama de la promesa cumplida

Id., Epigramas IV

Id." "La materia

Id., Blancanieves III

Id., Fuera del mundo 5

$C L$, Aquel instante

Id, Dimisión de Sancho, VII, Id Las tentaciones de Antonio, II,

$H$, Pedro Salinas III

$I d$, Bajo la lluvia de fuego

$I d$, Self-pity

$Y O P$, Tentativas terrestres, 20

Id, Clave de misterio, 18

Id, El gran inquisidor II

Id, Américo Castro

Id, Cántico 16

$I d$, Reviviscencias 43

$F$, De la vejez 1 ,

$F$, Un nombre

\section{-TÉRMINO: 8 casos}

Sin referencia a comunes términos Va convergiendo hacia su seco término

Hacia su muerte. Sí, chocaron: término Hacia posible creación sin término Mi tiempo no tendrá para su término Gaviotas cruzan hacia un solo término Homicidios políticos sin término Mi posible tarea en esos términos

$C L$, Lugar de Lázaro I

$C L$, Silenciosamente

$Y O P$, Muertes

$Y O P$, El árbol de la historia

$Y O P$, Clamor

$F$, Playa de primavera

$F$, Lo pésimo

$F$, Un nombre

\section{-ATMÓSFERA: 7 casos}

La transparencia en mole de la atmósfera Más acá se difunde por la atmósfera Aquel, aquel verano con su atmósfera Ímpetu sin cesar hacia su atmósfera Que envuelve y ya anula en su atmósfera Pura, precolombina tanta atmósfera $Y$ de pronto se siente en otra atmósfera

$C$, El diálogo

$C$, Otoños

$L$, Aquel instante

$Y O P$, Arte rupestre

$Y O P$, Dos niveles

$Y O P$, Clamor

$F$, Dánae 
-PÁJARO/S: 7 casos

¿Es tal vez una siesta con un pájaro

Apenas corporal no siendo pájaro

Sin titubeo te respondo: pájaro

Erguida la mujer, volante el pájaro

Razón de amor y cántico de pájaros

Volaron por el aire más que pájaros

Gorgeo entrecortado de los pájaros

-MÚSICA: 5 casos

Ímpetu de un instinto que es ya música

Una niñez feliz, la buena música

Nuestro deseo implícito de música

Eros resuelto en forma, gracia, música

Que envuelve cuerpo y alma en una música

-NÍTIDO/A/S: 4 casos

Es aspereza de horizonte es nitida

De plumajes, charoles, armas nitidas

$Y$ en más luz se convierten: la más nítida

Rumores de motoires. ¡Rutas nítidas!

\section{-CREPÚSCULO: 4 casos}

Y a ciegas se dirije hacia un crepúsculo Oponiéndose adornan el crepúsculo Esfumándose van en el crepúsculo Se vuelve lago, lago de crepúsculo

\section{-ÁLAMO/S: 4 casos}

Luz en el agua, son entre los álamos Luz en el agua, son entre los álamos Los mirlos buscarán alturas e álamos Poco decía, juvenil, un álamo

\section{-FÁBULA/S: 4 casos}

Según la sombra de sus propias fábulas Y a mi atención le descubren su fábula Tras haber concebido tantas fábulas Sus autores. La vida es una fábula
$C$, Hasta la sombra

$C L$, El jardín de los coqu4ies

$Y O P$, Historias naturales

$Y O P$, Cántico

YOP, Guido Cavalcante

$F$, Tiempo de espera

$F$, Un paseante solitario
$H$, Picasso

YOP, Despedidas XIV

$F$, Al lector

$F$, Bailar

$F$, Orgía
$C$, El diálogo
$C L$, Potencia de Pérez VIII
$C L$, Luzbel desconcertado IV
$C L$, Aire con época.

Un número elevado de esdrújulos en posición final son adjetivos superlativos, de lo cual se ha visto más arriba un antecedente en Espronceda. Tan notable frecuencia traduce la voluntad de exaltación que recorre la obra de Guillén. Se han recogido los siguientes:
$C$, Nivel del río. Verso inicial.
$C, I d$., Repetido al final del poema.
$C$, El viaje
$F$, Epigramas II

$H$, Al margen de Erasmo $H$, Con los ojos abiertos $Y O P$, Emilio Salgari y su editor $Y O P$, Reviviscencias 60 
-SUPERLATIVOS:

Angustiosa, gozosa, perfectísima La Nada, maravilla perfectísima? Hombres, hombres expertos, sagacísimos Entre medias palabras y clarísimos Desde aquella conciencia remotísima Y quizá la conciencia remotísima Su ingenuidad de tránsito brevísimo Que la verdad, acorde simplicísimo De ser hombre pequeño, pequeñisimo Por espacios y espacios remotísimos La voz propia al diálogo vivísimo Se contrajo a una vida correctísima Sus caprichos pacientes, pacientísimos Hoja de lata, ruinas modernísimas Se tiende hacia las calles, humanísima De flor dificil, rara, sutilísima De los amantes, siempre lejanisimos Mar, un alba serena, serenísima Respiración. Del fuego, sí. Purísimo Infames a cristianos correctísimos La máquina de amar es perfectísima Son rojizo con rayos agudísimos Amenaza la plétora gravísima Sentí una somnolencia pesadísima Aves volaban altas, cielo altísimo ¿No es su entrega la guía nobilísima Protagonista firme, tenacísimo En una perspectiva pesadísima La Historia es un deporte velocísimo La audición de un transcurso delgadísimo ¿O será esto un sueño pesadísimo Muy flexible, muy leve, sutilisima Sobre instante libérrimo, bellísimo Según estricto ritmo perfectísimo $Y$ volvió a la alabanza del Altísimo Aquel esclavo griego era bellísimo Feliz, indiferente, lejanísimo Oh doble ingenuidad y felicísima Ah, María Victoria serenísima Rollizos y triunfantes, humanísimos Historia imprevisible y completísima

$C$, Luzbel desconcertado

$C L, I d$.

$C L$, Guerra en la paz II

$C L$, Tu más allá

$C L$, Las tentaciones de Antonio

$C L, I d$. II

$C L$, Silenciosamente

$H$, Al margen de Cicerón

$H$, Al margen de Pascal

$H$, Al margen de Novalis

$H$, Pedro Salinas II

$H$, Harún el cobarde

$H$, Encuentro final

$H$, Desemboque y frontera

$H$, Los cerros de Bogotá

$Y O P$, La orquídea

$Y O P$, Ariadna en Naxos III

$Y O P$, Nocturnos 16

$Y O P$, En estos años de tormentas VIII

$Y O P$, Hombre y luna 29

$Y O P$, Anterior al paleolítico

$Y O P$, Cántico 15

$Y O P$, La sibila

YOP, Id.

$F$, Los buitres

$F$, Más amor y pedagogía

$F$, Sombra y corazón

$F$, De la vejez 5

$F$, Maneras de respirar 2

$F$, Id 24

$F$, Id 30

$F$, Epigramas I

$F, I d$., II

$F$, Id III

$F$, Job, múltiple doliente

$F$, Suicidio comprensible

$F$, Desde fuera

$F$, Gabriel Miró

$F$, MaríaVictoria Atencia

$F$, Casi metamorfosis

$F$, Arte de terror II.

Se observa que el número mayor de superlativos se encuentra en los poemas del libro Final. Salvo error, el número total de superlativos es de 41 , y siendo el de esdrújulos 562, la proporción resulta relativamente elevada: 7'29\%. 
Los tres poetas mayores Unamuno, Juan Ramón Jiménez y Jorge Guillén han utilizado el endecasílabo esdrújulo con libertad, a veces con frecuencia aproximadamente equivalente a la del endecasílabo agudo, llegando ese verso a perder el peso que la tradición le imponía para hacerse, al contrario, vehículo de sentimiento, de pensamiento o de exaltación.

Hay un verso en la obra de Gerardo Diego que por sí solo revela que la palabra esdrújula y el verso esdrújulo son en él también abiertamente adoptados:

poseyéndole en ímpetu genésico

(Mi Santander, El padremadre mar)

Se encuentran en su obra toda clase de combinaciones, concurrencia de voces esdrújulas en un mismo verso:

Fábula agraz de rámilas y zorras

si navegan los pájaros sin práctico y el corazón, y el cálculo y la brújula

tres de ese globo o lágrima magnánima

en versos contiguos:

tan soberbia en su luz, escondes trémula cristales piadosísimos de lágrimas siguiendo con la yema de su índice el perfil prodigioso, el anca eléctrica

o contiguos aconsonantados:
(La luna en el desierto, Castilla milenaria)

(Biografia incompleta, El hombro)

(Amor solo, No verte)

(Mi Santander, Monólgo del capitán aeronauta).
(Glosa a Villamediana, Libra)

(Vuelta del peregrino, Milagro en Altamira)

Pero en su noche, toda hundida en mármoles,

un pueblo en las raíces de los árboles (Tántalo, El cementerio marino)

Se encuentran con cierta frecuencia con palabras llanas que se cambian en esdrújulas por adición de un pronombre enclítico como se vio también en Unamuno y especialmente en El Cristo de Velázquez. He aquí algunos de ellos:

oh mi hermano en María, transfigúrame

preserva mi figura, transfigúrame

cayéndose en el aire, tropezándose

y el alma siempre pura, azul, negándose
(Versos divinos, Salmo de la

(Id) transfiguración)

(Amazona, Psique II)

(Mi Santander, Manuel Llano) 
que gira y gira y gira desgastándose

(Vuelta del peregrino, Voz de Federico)

cuando Dios te llamó y tú ahogándote

(Id. Ormola)

Alcanza esta construcción un punto máximo en los siguientes, en los que aparecen tres formas gerundivas cambiadas en esdrújulas por adición de pronombre enclítico:

aliméntame, fúndame, concéntrame

desgarrándote, hundiéndote, salvándome
(Versos divinos, Adoración al Santísimo Sacramento)

(Vuelta del peregrino, Ormola)

Pero lo que caracteriza el esdrújulo en este poeta es el aire vanguardista de algunos de ellos; el poeta, efectivamente, incorpora al verso en posición final, aunque también en posición interna, palabras de uso no frecuente hasta entonces en la poesía. Algunas de esas palabras son: aerostático, acróbata, cálculo, eléctrico, filatélico, frayangélico, neumático, radiográfico, satélite, teléfono, vísceras y otros que se encuentran en versos de otras medidas, como andrómedas, masorético.

Esta tendencia destiñe, naturalmente sobre otros poetas de la misma generación. Se encuentran en la obra de Rafael Alberti bastantes casos. He aquí algunos de ellos:

Esqueleto de níquel. Dos gramófonos ¿Cómo olvidarte a ti, rosa mecánica, impasible, de pie, bajo el eléctrico sabed de mí, que dije por teléfono la intervención armada de los dólares
(Cal y canto, Sueño. Fracaso)

(Ibid.)

(Id. Carta abierta)

(De un momento a otro, Yo también canto a América))

Son numerosos los casos de palabra llana cambiada en esdrújula por enclisis de pronombre, pero en posición interna:

Mama la luz y agótala, criatura, tabícala en tu ser iluminado

firmándose una ley marcial, oscura
(Entre el clavel y la espada, Soneto corporales, I)

(Entre el clavel y la espada, De pensamiento en un jardín).

No podían faltar en la obra de Alberti el nombre de la tierra donde vivió parte de su exilio y, en efecto, el nombre de América aparece en posición interna: 
en la noche de América -decírtelo

o ensalzado en posición final:

Quiero decirte, toro, que en América

En la noche de América-decírtelo
(Entre el clavel y la espada, Metamorfosis del clavel, 17)

sin olvidar a Aitana de América, su hija que aparece en algún poema con esa definición.

Luis Rosales nos ofrece un verso de alta significación, no sólo por el relieve que cobra el esdrújulo final (náufragos), sino porque sitúa bajo el acento de la $6^{\mathrm{a}}$ sílaba la palabra "Dios" creando así entre su significado y el del esdrújulo final un contraste abrupto:

y en el mirar de Dios seremos náufragos

(Rimas)

En poetas anteriores se han encontrado diversos casos de concentración de esdrújulos en un mismo conjunto estrófico, en versos contiguos o en un solo y mismo verso. Luis Rosales ha escrito algunos versos de esas características en los que además aparecen formas enclíticas:

deshaciéndose en olas, deshaciéndose

amándote, olvidándote y negándote
(Id.)

(Aprendiendo a ser hombre).

Juan Gil-Albert, en cambio, utiliza en número bastante elevado esdrújulos en posición interna y bastante escasos en posición final. Dos ejemplos de endecasílabos esdrújulos son:

de Bathilo los bucles dionisíacos

inalcanzable el ansia del arqueólogo
(Fuentes e la constancia)

(Id.)

Un somero repaso de los números de la revista Garcilaso, Juventud creadora (1943-46) comprueba que los poetas jóvenes de posguerra utilizan el verso endecasílabo esdrújulo sin inconveniente de ningún tipo. Se encuentran en poetas de diversa personalidad como lo son Rafael Montesinos, Vicente Gaos, Leopoldo Panero, Pedro Lezcano, Julio Maruri, Juan Ruiz Peña, Carlos Salomón y otros. Un autor anónimo publica en la sección 
"Galería de retratos" en el número 14, un soneto al que pertenecen los dos tercetos finales siguientes y que curiosamente viene a enlazar con aquella antigua tendencia a admitir el verso esdrújulo solamente con asuntos de tipo burlesco o jocoso. La persona retratada es Dámaso Alonso:

Tú, Sancho voluntario, ¿tú fanático?

¿tú rompiendo las lindes de la estética?

¿tú suelto? Tú, redondamente hermético.

El poeta ha vencido al catedrático.

Cuarenta... y cinco años de poética.

Alégrateme, Dámaso frenético.

Obsérvese este último verso compuesto sólo con palabras esdrújulas.

La exploración realizada en otros poetas (Ramón de Garciasol, Luis López Anglada, José García Nieto, Carlos Bousoño), confirma lo hasta ahora ya comprobado, es decir, que el endecasílabo esdrújulo tiene patria en la poesía moderna con las mismas aspiraciones que las otras palabras de que dispone el poeta. El verso esdrújulo es frecuente en algunos, menos utilizado en otros, casi ausente en algunos, pero en todos ellos su adecuación al poema es total.

Cabe citar, sin embargo, al poeta que en la segunda parte del siglo ha aportado a la poesía un lenguaje innovador: Carlos Edmundo de Ory, que no deja de tener cierto parentesco casual con otro poeta innovador de principios de siglo: Julio Herrera y Reissig. Ambos han utilizado a veces palabras esdrújulas en posición final aconsonantada con elección de vocabulario y estructuras que revelan un parentesco espiritual detectable. En Soneto vivo de Carlos Edmundo de Ory, se incluye el titulado "Derecho internacional" al que pertenecen estos dos serventesios:

Toda la noche la pasé en análogo pensamiento de darme a la tremenda de no poner los pies en el decálogo

$y$ de soltar las manos de la rienda

Quiero leyes al margen del catálogo

Pronunciar yo el discurso de la enmienda 
del hombre a solas con su triste diálogo que no hay cabeza humana que lo entienda

Antonio Carvajal no desdeña el verso esdrújulo:

alguien secaba de tu rostro lágrimas

Tanto silencio silba entre las trémulas resumido en un pulso vago y múltiple Zape la noche con difusos ángeles y se tiende a tu lado como dádiva
(Raso milena y perla, Escena de tormenta)

(Id. Tema y variaciones)

(Id. Tema y variaciones)

(Id. Invocación)

(Id. Piedra de fuego)

Se observa en los poemas de este libro una recurrencia de algunos esdrújulos finales y en particular de "espíritu":

Gime la carne gozos del espíritu me hace gemir la carne del espíritu
(Id., Corona de madrigales I)

(Id., Corona de madrigales, II)

Interesa resaltar cómo a partir de dos palabras esdrújulas y una llana, el poeta construye una arquitectura en la que los elementos se absorben unos a otros, adquieren unos el papel de los otros, confunden sus esencias y crean así un clima poético personalísimo:

Pluma, pétalo, pálpito. Las plumas

negras, sobre los pétalos con pálpitos

más leves cada vez. Los blanco pétalos

sobre las negras plumas a la vez

tan leves. Con un pálpito de pétalos

la pluma cae al alma y la desnuda.

(Raso milena y perla.).

Este trabajo viene a ser complemento del que se ha dedicado al endecasílabo agudo en el volumen 3-4 de la revista Rhythmi$\mathrm{ca}^{13}$

La investigación en la poesía española realizada ha respetado la cronología, lo cual permite observar la evolución histórica en la adopción de los versos endecasílabos esdrújulos. El estudio del empleo de la palabra esdrújula en posición final es inseparable del empleo en posición interna, pues se ha observado con frecuencia que se establecen entre las palabras esdrújulas en ambas posiciones, relaciones fonéticas y/o semánticas de interés.

\footnotetext{
${ }^{13}$ In Rhythmica, Año III-IV, Número 3-4, Sevilla, 2006, 209-251.
} 
El empleo de las palabras esdrújulas por los poetas se ha enriquecido desde el modernismo, de tal manera que no solamente las censuras antiguas se han disipado, sino que además en bastantes casos el empleo del esdrújulo es altamente significante.

Sirvan ahora para cerrar este trabajo otros versos del mismo Jorge Guillén que expresan con nitidez todo el misterio que infunden en el ritmo las palabras y sus acentos:

Por el río del ritmo las palabras

Transcienden su inmediato ser sonoro,

Proponen más riqueza de sentido,

Algo con fluidez de sentimiento

Que a lejanías llevan ciertos sabios

Signos, no extravagantes, misteriosos.

¡Córdoba! "Tábida, lúrida” Córdoba! （F., La expresión, 14, II).

Y termina la estrofa anterior -que se inicia con los esdrújulos ya señalados, "tábida"y "lúrida"- refiriéndose a los términos usados por los poetas:

Todo conduce al umbral del misterio.

(Id., 14, I). 